\title{
A TRANSLATION INTO ENGLISH OF KHALIL I. AL-FUZAI'S “EURHYTHMICS ON THE PAVEMENT OF DANGER"[1]
}

\author{
Gassim H. Dohal ${ }^{*}{ }^{\circledR}$ \\ ${ }^{* 1}$ Gizan, Saudi Arabia
}

DOI: https://doi.org/10.29121/granthaalayah.v8.i12.2020.2703

Article Type: Research Article

Article Citation: Gassim H. Dohal. (2020). A TRANSLATION INTO ENGLISH OF KHALIL I. AL-FUZAI'S "EURHYTHMICS ON THE PAVEMENT OF DANGER". International Journal of Research GRANTHAALAYAH, 8(12), 247-250. https://doi.org/10.29121/granthaa layah.v8.i12.2020.2703

Received Date: 07 December 2020

Accepted Date: 31 December 2020

Keywords:

Journalism

Al-Fuzai

Saudi

Short Story

"Eurhythmics on The Pavement of Danger"

\begin{abstract}
Khalil I. Al-Fuzai (1940-) is a man of letters from Saudi Arabia who published few collections of stories. In these stories he tries to introduce his characters in a simple, frank way (see Dohal 2013). One of these stories is "Eurhythmics on the Pavement of Danger." Here he addresses the issue of journalism. I chose to translate this story for it is a good sample of how Al-Fuzai has connected between journalism and war (see other themes he addresses in Dohal, 2013, 2018 \& 2019). Furthermore, it presents some aspects what has happened in 1991; this story has a part of history.
\end{abstract}

\section{INTRODUCTION}

In this short story, some journalists decide to take risk and enter a war area. Such a risk may lead to unexpected consequences. Yet, it is a way of depicting what is taken place. Nowadays, TV channels have correspondents who communicate from battlefields all over the world. The journalists of this story face some difficulties before being able to arrive at "a free Kuwait."

Al-Fuzai manages to draw a live picture a reader can enjoy and live. Indeed, he is a journalist who used to write for few newspapers, particularly Al-Youm (Dohal 2013).

\section{TRANSLATION}

\section{Eurhythmics on the Pavement of Danger}

Fear .. [2] horror .. a lot of rain .. a sign of a new month's birth, new period, with the flash of continuous explosions . . the lights flashes from the far . . the circle of light goes to distances that allow (people to) see the sad 


\section{A Translation into English Of Khalil I. Al-Fuzai's “Eurhythmics on The Pavement of Danger"}

buildings that are being destroyed .. the facets of other (buildings) provide with a protection .. in the focus of that light, their utterance see the light, such terms as resistance, liberation .. evacuation.

The small car with which I and the magazine photographer slip into the border .. it does not permit us to proceed further after its wheels penetrate deeply into the soil which has changed into mud due to the heavy rain. So, we have to leave it near the outskirts of the city and start our risky trip on foot, and the goal is that we want to be the first journalists to arrive at the liberated city of Kuwait [3] in the morning . .explosions deafen our ears .. the explosion of a mine under our feet is expected at one moment or another . . the smell of the burnt oil is mixed with that of rain and muddy ground, and on the road the sprinkles of the rain disperse whenever a speedy military car passes, while spread on both sides of the road, burnt civil cars are not far from each other. They can be seen perching like ghosts on the light of consecutive explosions. We used to hear the news of cease-fire from the radio of the car, but now we are isolated from the world.

After a while the fear-and-caution-engulfed walking . . there is a not-clearly marked military jeep car .. fear .. hesitation . . courage, we do not approach it until one of them takes out his weapon asking about evidence of our identities .. when one of the allied-army soldiers realizes who we are, he starts blaming us for this unsafe risk. . three soldiers find no way but to take us with them to the city which starts shaking off its burden, the dust of the suffocating months of occupation, as if the rain cooperates to have its water erase the traces of the aggressors.

Danger emerges with every step we take and the flames become clear from burnt buildings, and the defeated enemy leaves in groups toward Al-Mitlaa [4] as a soldier announces after a call he made with the communication device he is carrying, and he is not mistaken for the happy tone of his voice when he tells us about that.

Across the muddy streets, the jeep forces its way with caution .. in front of the Intercontinental Hotel, a few soldiers gather .. the entrance to the hotel is dark, some soldiers have been using manual light for their movements, and in the hall of the hotel, the military bags, which soldiers used to carry on their shoulders, are piled up .. our presence with our civil clothes among them is noticeable, some officers suggest we wear military clothes with a red crescent sign, and after that we are advised to stay in the hotel which was the headquarters of the enemy, they say that it is a precautionary measure .. the rooms and the halls are dark .. the whole hotel is dim ... we prefer to stay in the hall talking with the soldiers .. recording their impressions toward war and liberation .. some of the female recruits exchange opinions .. I feel confused when I get close to them, and instead of asking .. one of them inquires about the nationalities. I tried to answer in broken English . . a conversation takes place and I understand that they are from the American Navy . . they are beautiful to the level it becomes hard to imagine their presence in this crazy war . . but it is the war game that has no common measures, and that denies all familiar scales to the extent that concepts are mixed so that they are hard to comprehend.

When the light of the manual lights come across their slender bodies, those bodies seem as if they were ghostly in shape .. which clear away the gloominess of the place where the ghosts of fear have prevailed; those females appear as if they are on an amusement trip.

The night is about to leave when a present-minded dream settles the heart .. in the moments of happiness and hopelessness . . in the minutes of certainty and despair . . in the hours of hope and pain .. in the days of optimism and pessimism and in the nights of dreams and reality, the moon slumbers in her eyelids, and on her braids the night stars scatter, but they become letters erased from the universe by destiny even when they still live in the heart. . torn dreams and burnt desires.

I became acquainted with her when we studied communication at Kuwait University . . a story of love grew between us and became the topic of our colleagues' talk . . even our families' topic .. we intended to marry in a few years after our graduation.

One day, I said to her, "Tomorrow when each of us goes to his country .. how can one entertain the self without the other?"

She said, "And why does one entertain the self without the other? . . you live with me in the heart, oh my eye."

"And you are living with me as well in the heart, oh my heart."

"The day of our marriage will be the day of my real birthday."

And we graduated . . each returned to his country .. each worked as a journalist . . but . . but she died while reporting from the front in the Al-Ahwar region [5] .. she is one of the millions of victims whom the war of the eight lean years pulverized .. here I am after her death .. I still love her and the memory .. I remember her in every lovely woman . . in every overtaking danger . . in every quiver of a heart . . in every flicker of emotion . . am I going to meet the same fate (she had) on this mission .. despite the annoncement that the war has ended at the official level? 
With the first sign of dawn .. and with the sneaking of the first threads of the sun's rays through the accumulated clouds and the smoke of the fire of the oil wells .. all in the hotel hall do still talk about the accomplishments of the allied armies . . the attack against the Iraqi military targets . . the land battles . . the withdrawal of the Iraqis from Kuwait . . the fatal blows that were aimed at them in Al-Mitlaa when the planes showered them with a thousand tons of vacuum bombs, which shook the ground, and the smell of the grilled bodies reached distances, after the bodies charred in the tanks. The cars which were fleeing from the hell of the battle met a hell that was severer and fiercer.

On this day, which is the first of March . . colleagues of the same profession start arriving from all over the world, in order to report the entrance of the allied armies in a free Kuwait, and because we arrived a few hours earlier than them, we became the object of others' attention, and that granted us unforgettable memories.

Among the waves of happiness . . her face appeared calm, assured . . as if she wants to share (us) in this unique happiness.

$$
4 / 5 / 1995[6]
$$

\section{CONCLUSION}

As indicated above, Khalil I. Al-Fuzai is a man of letters who tries to present what is going in his local area in a simple journalistic method (Dohal, 2013). This story addresses the consequences of taking a risk during a war time. Regardless of your mission, it is war. However, journalists are our source of news at all situations; we need them more during the time of war. They represent to their followers originality, credibility, and to some extent reality when they report from the battlefield. All this requires sacrifices and challenges; this is what this story is about.

\section{TRANSLATOR'S NOTES}

1) "Eurythmics on the Pavement of Danger": this story was found and translated into English from the following Arabic source:

2) Torture That Does Not Die. العذاب الذي لا يموت Dammam: Eastern Province Literary Club, 1998: 81-89.

3) ... Every now and then there are two dots in the source text.

4) The city of Kuwait: capital of Kuwait State.

5) Al-Mitlaa: name of a place.

6) Al-Ahwar region: Iraq's southern marshes.

7) 4/5/1995: date found in the source text.

\section{SOURCES OF FUNDING}

This research received no specific grant from any funding agency in the public, commercial, or not-for-profit sectors.

\section{CONFLICT OF INTEREST}

The author have declared that no competing interests exist.

\section{ACKNOWLEDGMENT}

None.

\section{REFERENCES}

[1] Al-Fuzai, Khalil. العذاب الذي لا يموت Torture That Does Not Die. Dammam: Eastern Province Literary Club, 1998: 81-89.

[2] As-Shabat, Abdullah A. "Khalil Al-Fuzai." من الخليج العربي أدباء و أدييات (Men and Women of Letters from the Arabian Gulf.) Khubar: The New National House for Publishing and Distribution, 1999. 
[3] Dohal, Gassim. H. A Translation into English of Khalil I. Al-Fuzai's "The Crazy Street". International Journal of Comparative Literature and Translation Studies, 6(4), 2018: 1-4. http://dx.doi.org/10.0001/ijllis.v7i11.1791

[4] ------- An Intoduction to and a Translation into English of Khalil I. Al-Fuzai's "Thursday Fair". Advances in Language and Literary Studies, 10(2), 2019: 121-123. http://dx.doi.org/10.7575/aiac.alls.v.10n.2p.121

[5] --------Khalil I. Al-Fuzai: A Writer from Saudi Arabia. Asian Journal of Multidisciplinary Studies (AJMS), 3(2), 2015: 166-67. Retrieved http://www.ajms.co.in/sites/ajms2015/index.php/ajms/article/viw/870/701

[6] -------.Khalil I. Al-Fuzai: Life and Contributions. International Journal of English and Literature (IJEL), 3(5), 2013: 53-60. http://www.tjprc.org/publishpapers/2-40-1384512377-9.\%20Khalil.full.pdf. 